\title{
Endoparasite community of Rattus norvegicus captured in a shantytown of Buenos Aires City, Argentina
}

\author{
D. HANCKE ${ }^{1}$, G. T. NAVONE ${ }^{2}$, O. V. SUAREZ ${ }^{1}$
}

\begin{abstract}
${ }^{1}$ Laboratorio de Ecología de Roedores, Departamento de Ecología, Genética y Evolución, Facultad de Ciencias Exactas y Naturales, Universidad de Buenos Aires, Buenos Aires, Argentina, E-mail: diegohancke@ege.fcen.uba.ar;

${ }^{2}$ Centro de Estudios Parasitológicos y de Vectores CEPAVE (CCT-CONICET-La Plata) (UNLP), Calle 2, $\mathrm{N}^{\circ}$ 584, 1900 La Plata, Buenos Aires, Argentina
\end{abstract}

\begin{abstract}
Summary
The aim of this study was to evaluate the role of the brown rat (Rattus norvegicus) as a potential reservoir of zoonotic parasites in an urban area of Argentina. A parasitological survey in 40 brown rats trapped in a shantytown of Buenos Aires City was carried out. $97.5 \%$ of the analyzed rats were parasitized with at least one of the 12 species of helminth or protozoan species recorded. Among the species identified, Hymenolepis nana is recognized as one of the most common human helminthes parasites. The average number of parasite species was higher in males than females rats, and in the last case, a direct relationship between parasite species richness and host's body size was recorded. Variations in endoparasite community throughout the year seasons were recorded, probably related to environmental factors, which limits the performance of the life cycle of different parasite species. The presence of zoonotic endoparasites confirms $R$. norvegicus as a reservoir for different types of pathologies, which, therefore, represents a risk to the public health in an overcrowded urban area.
\end{abstract}

Keywords: Rattus norvegicus; endoparasites; zoonosis; shantytown; Buenos Aires

\section{Introduction}

Synanthropic rodents play a significant role in human health, welfare and economy due to its close association with man (Stojcevik et al., 2004). Particularly, rodents of genus Rattus are recognized as reservoirs of several viral (Hantavirus, arenavirus) and bacterial pathogens (e.g. Yersinia enterocolitica, Leptospira spp., Rickettsia akari) (Coto, 1997; Enría \& Levis, 2004). Among the most common parasitic diseases are included giardiasis, hydatid disease, trichinellosis and several helminthiasis such as the tapeworms Hymenolepis nana and $H$. diminuta (Acha \& Scyfres, 1992; Coto, 1997).
Following Bradley and Altizer (2006), high densities of animal population adapted to urban environments could favour the parasite transmission to other species, including man. Rattus norvegicus is one of the most important commensal animals, and it's distributed worldwide in human settlements (Traweger et al., 2006). It presents a high adaptive capacity and opportunistic behaviour, which makes the brown rat very successful in urban environments and its presence can mostly be correlated with inadequate disposal of anthropogenic waste (Traweger et al., 2006). Studies conducted in the city of Buenos Aires (Argentina) showed high abundance of $R$. norvegicus in slum areas, like shantytowns, where the environmental and social characteristics generate the appropriated conditions for the development of this species (Fernández et al., 2007; Cavia et al., 2008).

For the design of disease control programs, it will become increasingly important understand the ecology of pathogens in urban environments and the mechanisms shaping within host-parasite communities (Bradley \& Altizer, 2006; Pedersen \& Fenton, 2006). Many factors affect the structure of parasite communities including biogeography and phylogenetic history, host specificity, and parameters of host biology such as population size, habitat, diet, dispersal and antiparasite defence (Poulin \& Morand, 2004). To date, parasite community ecology has been highly descriptive driven by analysis based on parasite abundance patterns at the host population level (Pedersen \& Fenton, 2006). The complexities of the relationships among infectious agents, including parasites, their animal and human hosts and the environment, has led to an approach that encompassed all potential contributors to the pathogens behaviour in an ecosystem, known as disease ecology (Real, 1996; Polley, 2005). Although the parasite fauna of Rattus spp. has been well descript in different parts around the world, in Argentina, particularly in the city of Buenos Aires, the records are poor. The first aim of this study was 
to identify the endoparasite species of $R$. norvegicus in a slum area of the city of Buenos Aires to determine the role of $R$. norvergicus as a potential reservoir of zoonotic parasites. A second aim was to study the variations in the patterns of parasite infections in the course of a year and determine the effect of host characteristics on the composition of parasite community.

\section{Materials and methods}

\section{Study area}

This study was carried out in a shantytown of Buenos Aires City (34 34' 50.89', S; 58 $23^{\circ}$ '02.28' 'W) located in a neighbourhood close to the city centre. According to data from the last census, this shantytown occupies an area of $190.000 \mathrm{~m}^{2}$ and is inhabited by approximately 12.242 people (INDEC, 2001). But since then the population has been continuously expanding.

\section{Rodent trapping}

Sampling was conducted between November 2003 and August 2004, and between October 2006 and August 2007. Live trappings were performed every two months in both periods using cage traps $(15 \times 16 \times 31 \mathrm{~cm})$ for four consecutive nights. Traps were baited with meat and carrot and placed inside houses and their yards or gardens. Captured animals were collected each morning and carried to a field processing station. Animals were anesthetized with an intramuscular injection of ketamine hydrochloride (75 $\mathrm{mg} / \mathrm{kg}$ ) with acepromazine (2.5 $\mathrm{mg} / \mathrm{kg})$, sexed, measured and weighted.

\section{Parasitological examination}

A total of $40 R$. norvegicus specimens were analyzed, 10 per each year season. The samples were selected according to sex and physical characteristics of the specimens so that all seasonal samples were homogeneous and that the sex ratio does not deviate from $1: 1$. The organs of the digestive system were removed from the rats and transferred to individual Petri dishes. The liver was examined, and the entire alimentary track was slit lengthwise, and the gut content was observed. Samples of faeces were taken to obtain protozoa cyst and helminths eggs. The presence and identification of helminth eggs and protozoa was performed by applying flotation and sedimentation coproparasitological enrichment techniques (Willis and Ritchie methods respectively) (Navone et al., 2005).

\section{Statistical analysis}

The following infections parameters recommended by Bush et al. (1997) were calculated for each parasite species identified: prevalence $(\mathrm{P})$, intensity $(\mathrm{I})$, mean intensity $(\mathrm{mI})$ and abundance (A). For each of the parasite species population, we examined the effect of sex and host trapping season on prevalence using maximum likelihood techniques based on log-linear analysis of frequency tables (Zar, 1996). For each species in turn we entered prevalence of infection as a binary factor (infected $=1$, not infected $=0$ ) and then sex (two levels: male and female) and season (four levels: spring, summer, autumn and winter) as factors. Differences in headtail length between infected and uninfected rats were analyzed using " $t$ " tests for independent samples. The relation between the intensity of each parasite species and host's body size was studied by lineal regressions (Zar, 1996).

To study the independence of species richness between infracommunities, the frequency distribution of these values was tested for goodness-of-fit to the Poisson distribution (assumption of the null model is a random distribution) by Chi-Square analysis (Zar, 1996). The constant of proportionality $(\lambda)$ was estimated from the sample. The variability of the species richness throughout all the year seasons was studied employing a one-factor ANOVA test. A " $t$ " test for independent samples was used to analyse the difference in species richness between male and female hosts. For analyse the combined effect of sex and host size on parasite species richness, a multiple regression was performed considering the sex as categorical variable, the head-tail length as continue variable and species richness as dependent variable. A square root transformation of the species richness values was applied to fulfil the assumptions of normality and homogeneity of variance (Zar, 1996).

The variation of endoparasite component community in $R$. norvegicus population was studied using a simple correspondence analysis (CA) (Jongman et al., 1987). The intensities of the species of parasites were used as variable, and the parasitized hosts as cases. The effect of the season and hosts variables on the values of the dimensions of the CA was interpreted in this analysis. The effect of the sex of the rats and the season, when they were captured, were analyzed using an ANOVA analysis in each case. Linear regressions were performed between the values of the dimensions of the CA and head-tail length and weight of the host.

\section{Results}

A total of 12 helminth and protozoan species were recorded (Table 1). The cestode $H$. diminuta was the only helminth found in the alimentary tract, whose prevalence was not homogeneous throughout all the seasons $\left(\chi^{2}=\right.$ $10.21 ; \mathrm{df}=3 ; \mathrm{p}<0.05)$, having the highest in summer $(\mathrm{P}=$ $70 \%)$ and being absent in winter $(\mathrm{P}=0 \%)$. An effect of host's body size was only detected in the nematode Heterakis spumosa, where a direct and positive association between the intensity of infection and the head-tail length of $R$. norvegicus was observed $(\mathrm{r}=0.465 ; \mathrm{p}<0.05)$. None of the helminthes populations showed significant differences in their prevalence regarding to host's sex or size. In the feces samples, cysts of protozoan were detected along with helminthes eggs, including species of nematodes whose adult's forms were not detected in host's digestive system.

Thirty nine of the 40 analyzed rats were parasitized with at least 1 species of protozoa or helminth $(\mathrm{P}=97.5 \%)$, and $92 \%$ of them carried more than one species. The average 
Table 1. List of parasite species collected from Rattus norvegicus, location in the host, stage, prevalence, mean intensity ( \pm standard deviation) and abundance

\begin{tabular}{|c|c|c|c|c|c|c|}
\hline & Species & Location & Stage & $\begin{array}{l}\text { Prevalence } \\
\qquad(\%)\end{array}$ & $\begin{array}{c}\text { Mean } \\
\text { Intensity }\end{array}$ & Abundance \\
\hline \multirow[b]{2}{*}{ Protozoa } & Giardia sp. & Feces & Cyst & 7.5 & - & - \\
\hline & $\begin{array}{l}\text { Other protozoa (Cryptosporidium sp. and } \\
\text { Entamoeba } \mathrm{sp.}\end{array}$ & Feces & Cyst & 5.0 & - & - \\
\hline \multirow{3}{*}{ Cestoda } & Taenia taeniaeformis & Liver & Larvae & 35.0 & $1.4 \pm 1.1$ & $0.5 \pm 0.9$ \\
\hline & Hymenolepis diminuta & Intestine & Adult & 35.0 & $8.2 \pm 8.2$ & $3.1 \pm 6.3$ \\
\hline & Hymenolepis nana & Intestine & Adult & 5.0 & $4.5 \pm 0.7$ & $0.2 \pm 0.9$ \\
\hline \multirow{5}{*}{ Nematoda } & Nippostrongylus brasiliensis & Intestine & Adult & 75.0 & $180.4 \pm 221.8$ & $\begin{array}{c}135.3 \pm \\
207.0\end{array}$ \\
\hline & Heterakis spumosa & Caecum & Adult & 77.5 & $32.8 \pm 30.1$ & $25.4 \pm 29.8$ \\
\hline & Capillaria hepatica & Feces & Egg & 30.0 & - & - \\
\hline & Toxocara sp. & Feces & Egg & 5.0 & - & - \\
\hline & $\begin{array}{l}\text { Other nematodes (Nematospiroidea sp. and } \\
\text { Strongyloides sp.) }\end{array}$ & Feces & Egg & 17.5 & - & - \\
\hline
\end{tabular}

Prevalence $(\mathrm{P})$ is the number of infected rodents with a particular parasite species divided by the number of examined host; mean intensity (mI) is the average number of individuals of a particular parasite species in all infected hosts; and abundance (A) is the average number of individuals of a particular parasite species in all the examined hosts, including both infected and uninfected hosts.

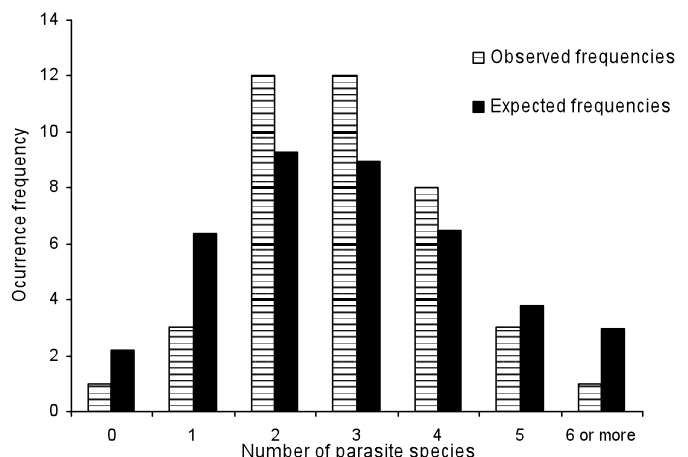

Fig. 1. Frequency distribution of infracommunity species richness (Predicted data are those expected by a Poisson distribution.)

number of parasite species was 2.9 per host, with a variance of 1.6 and a maximum of 6 . The observed values of endoparasite richness frequency did not show the difference with the expected frequencies fitted to a Poisson distribution $\left(\mathrm{c}^{2}=6.17 ; \mathrm{df}=5 ; \mathrm{p}>0.05\right)$ (Fig. 1), indicating the independence between the species richness values of each host.

No significant differences were found among the average seasonal richness values (mean species richness: spring $=$ 3.0 ; summer $=3.2$; autumn $=3.0 ;$ winter $=2.5 ; \mathrm{F}=0.534$, $\mathrm{df}=39, \mathrm{p}>0.05)$. Differences were detected according to host's sex, presenting males higher endoparasite richness (ER) than females (Males: average ER $=3.25 \pm 1.07$ species/host; Females: average ER $=2.40 \pm 1.45$ species/host; $\mathrm{t}=-2.097 ; \mathrm{df}=37 ; \mathrm{p}<0.05)$. The analysis of multiple regression presented a significant multiple interaction $(\mathrm{p}<$ 0.05 ), showing a positive relationship between ER and

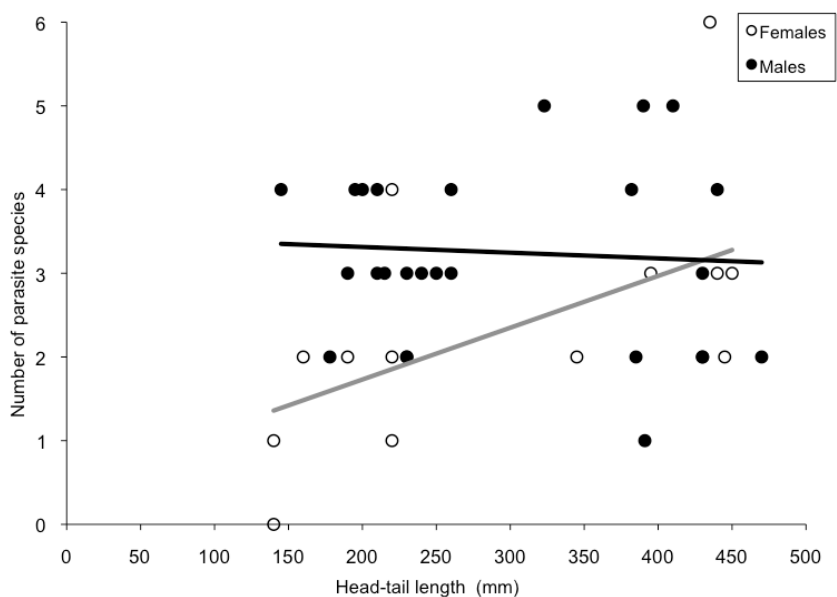

Fig. 2. Multiple regression between the head-tail length of Rattus norvegicus and their infracommunity species richness for males and females. The black line represents the regression for the males: Endoparasite richness $(\mathrm{ER})=3.53-0.03 * 10^{-6} *$ head-tail length (mm) and the grey line the regression for the females: $\mathrm{ER}=0.48+6.25^{*} 10^{-6} *$ head-tail length $(\mathrm{mm})$. 


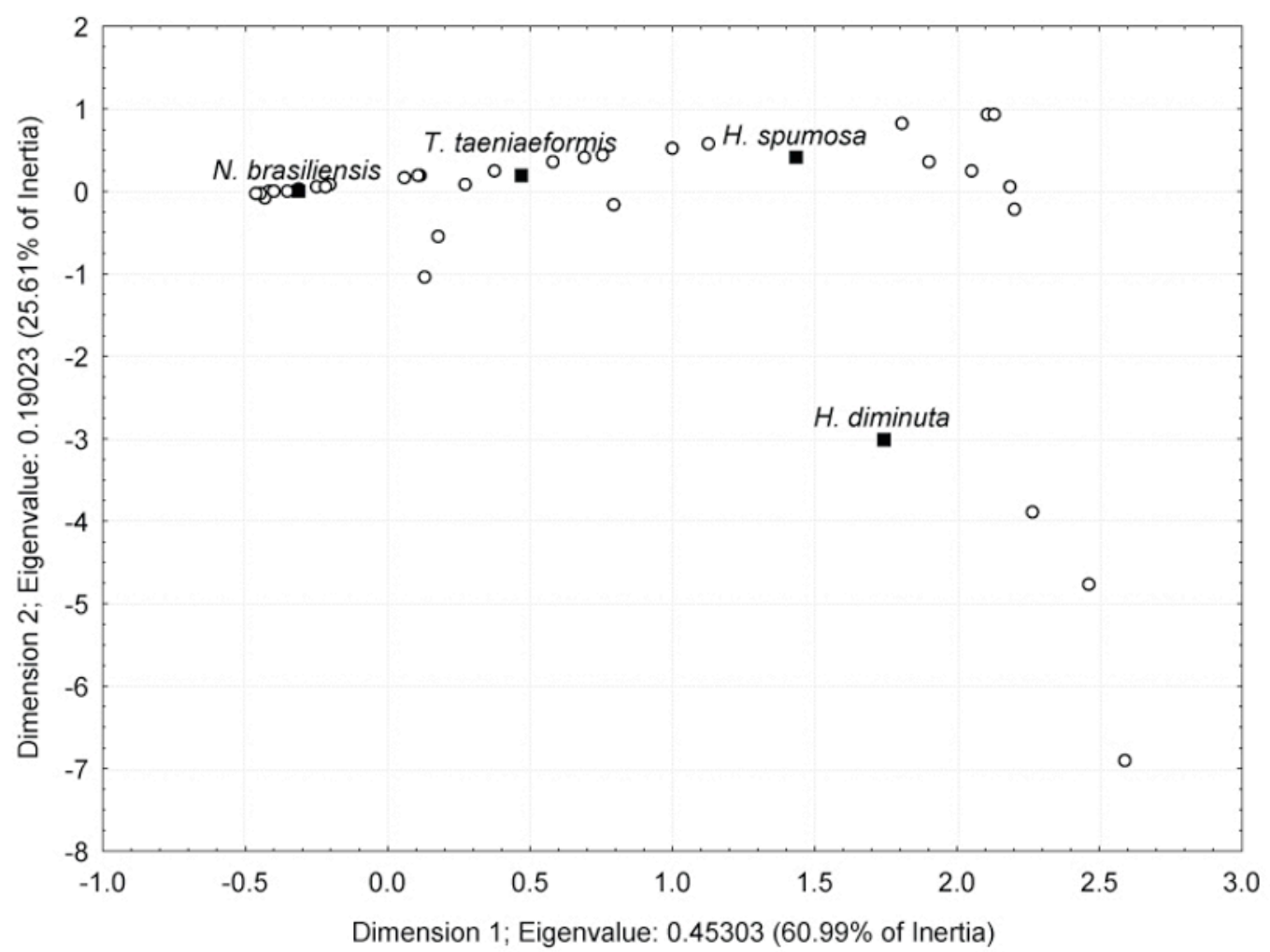

Fig. 3. Correspondence Analysis of the component community of Rattus norvegicus.

The empty circles refer to the hosts and the black squares to the parasite species.

host's body size in the case of the females, while no effect was seen in males (Fig. 2).

The correspondence analysis did not show the existence of groups of rats that contain markedly different endoparasite communities (Fig. 3). The dimension 1 of the CA explained a $61.0 \%$ of the total variance and did not put the hosts into groups according to its infracommunity characteristics. The Fig. 3 shows at the left of the graphic the infracommunities with high intensities of Nippostrongylus brasiliensis, and at the right side the ones with lower intensities of this parasite and higher $H$. diminuta and $H$. spumosa intensities. The dimension 2 explained a $25.6 \%$ of

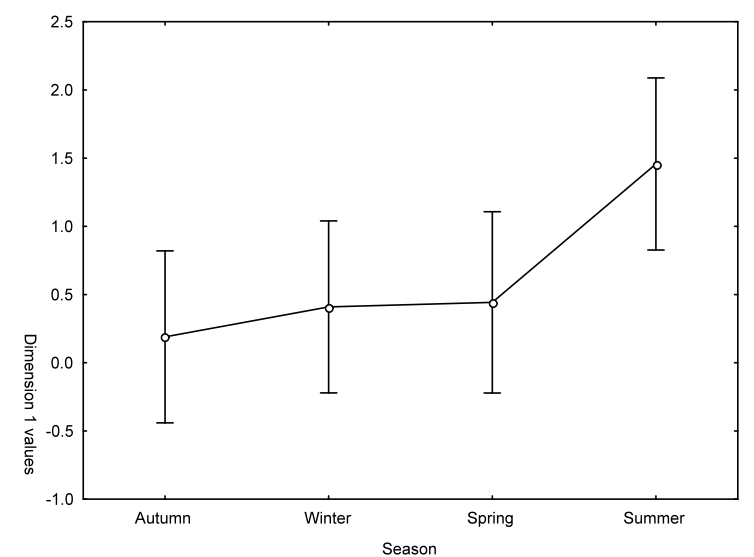

Fig. 4. Average of the Dimension 1 values from the Correspondence Analysis of the Rattus norvegicus component community for each year season when the hosts were captured (the bars shows $95 \%$ confidence limits) the total variance and only separated 3 rats from the rest of the hosts mainly because of the presence of $H$. diminuta as the predominant parasite species. It was noted, by analyzing the effect of hosts characteristics, that season was the only variable which contributes to the variability of dimension 1 values $(F=3.311 ; \mathrm{df}=38 ; \mathrm{p}<0.05)$. Applying Tuckey contrasts it was detected that rats captured in summer had higher values of dimension 1 than the ones captured in the rest of the seasons $(p<0.05)$ (Fig. 4).

\section{Discussion}

The results obtained confirmed the role of $R$. norvergicus as a potential reservoir of zoonotic parasites in a shantytown of Buenos Aires (Argentina). The species identified in this study have been descripted worldwide both in urban and rural environments (Battersby et al., 2002; Iannacone Oliver \& Alvariño Flores, 2002; Stojcevik et al., 2004). No digenean or acantocephalan species were detected, two groups of parasites already described in rats (Pham et al., 2001). Probably the presence or absence of the different parasite species is affected by environmental conditions of the study area, as well by the possible intermediate hosts that such species require to complete their life cycle.

Among the helminthes identified, $H$. nana is recognized as one of the human most common parasite. It is common in regions with warm climate and populations with low hygienic conditions and inadequate sanitary facilities (Mason \& Patterson, 1994). Studies carried out in different parts of Argentina showed the present of this parasite in humans, 
especially in children (Costamagna et al., 2002; Navone et al., 2006). The rat is also host for H. nana, which has a direct life cycle (Roberts 2000). In this study, we observed a low prevalence of this cestode $(5 \%)$, but this fact indicates that $H$. nana is circulating in the environment with a subsequent risk of transmission to humans. In contrast, $H$. diminuta had higher prevalence (35\%) and unlike $H$. nana, it is a typicall cestode of rats but infections in humans are not uncommon (Roberts, 2000).

The presence of Giardia sp. has also a sanitary importance since giardiasis is one of the most common parasitic diseases in Argentina (Luján, 2006). It's caused by flagellated protozoans of the genus Giardia ( $G$. lamblia) that inhabits the small intestine of man and other mammals (Thompson, 2004). However, molecular genetic studies are required to determine the species and genotype and, therefore, its zoonotic significance since there is no epidemiological evidence that animal-specific genotypes occur frequently in humans (Thompson, 2004).

$R$. norvergicus acts as intermediate hosts for Taenia taeniaeformis, whose adult lives commonly in the intestine of rat's predator, like cats. Infection occurs by accidental ingestion of eggs, which gives evidence of coprophagia in rats. This fact is supported by the presence of Toxocara eggs in rat's feces. Depending on the species, this parasite lives in an urban ambient in dogs or cats, and it is the causative agent of larval toxocarosis in humans. In addition, the presence of Capillaria hepatica eggs was detected in $40 \%$ of rat feces. This is a zoonotic nematode that inhabits the liver of many rodent species also occurs in a variety of wild and domestic animals and occasionally humans (Spratt \& Singleton, 2001; Resendes et al., 2008). The release of eggs requires host's death and a certain time in the soil at a suitable temperature and humidity conditions for development (Anderson 2000). The presence of $C$. hepatica eggs in rats may be due to cannibalism or saprophagia events or the fact that rats are feeding on feces of predators, like cats, contaminated with eggs of this parasite.

The parasites with highest prevalence were $N$. brasiliensis and $H$. spumosa. This species are common parasites of $R$. norvegicus around the world and are not mentioned as zoonotic, although their impacts on public health is unknown in densely populated environments. H. spumosa was the only of all the species detected that showed a direct and positive association with host's body size. Rats' increased body size allows presence of more individuals in their caecum. Gómez Villafañe et al. (2008) observed a similar tendency detecting a positive association between intensity of infection with $H$. spumosa and the age of $R$. norvegicus. Length is mentioned as a function of age in brown rats up to 5 months old (Kataranovski et al., 1994). Infection of this parasite occurs by ingestion of infective eggs from the environment and rats can retain infections around 150 days (Anderson, 2000). It's possible that bigger sized rats has been in contact with more infective sites than smaller ones, and have accumulated a more amount of parasites.
The number of endoparasite species per host showed differences according to the sex of $R$. norvergicus, having males a higher average number of species than females. Males of many species are mentioned to be more susceptible to infections than females which could lead, along with compartmental factors, to differences in their parasite community structure (Klein, 2000). A relationship between parasite species richness and body size has been detected in females and not in males. The body mass is positively correlated with factors that affect the pathogens transmission rates, such as hosts movement rates and food intake (Arneberg, 2002). Considering that big sized females are adult which should allocate their energy budget in activities such as reproduction, a possible explanation is that these activities demands some immune compromise reflected in an increase in their parasite fauna.

Although there was no variation in endoparasite richness throughout the year, correspondence analysis reveled that the rats captured in summer had higher abundances of $H$. diminuta and lower abundances of $N$. brasiliensis. In contrast, the abundance of $N$. brasiliensis was higher in the remaining months and $H$. diminuta was absent in winter. $H$. diminuta has an indirect life cycle necessarily needing an arthropod as intermediate host before moving to the final (Roberts, 2000). Probably the decrease of the incidence of this parasite in the colder months is related to that the intermediate host population is being affected by unfavorable environmental conditions. Besides, the decrease of $N$. brasiliensis in warm months could be explained considering the free living larval stages of this parasite which require moisture to survive because they are not resistant to desiccation (Anderson, 2000). The environmental conditions present during the summer would be limiting the survival of these stages in the study area.

Studies performed in different areas of the city of Buenos Aires showed the presence of antibodies against Seoul Hantavirus in $R$. norvergicus, and specifically in the shantytown were our study was conducted a $40 \%$ of $R$. norvergicus specimens were positive for Leptospira sp. by serological tests (Fernández et at., 2007; Cueto et al., 2008). The presence of zoonotic endoparasites detected in this study confirms $R$. norvergicus as a reservoir for different types of pathologies. Infectious diseases results from the interaction between the agent causing the disease, the host and the environment. These slums of Buenos Aires, characterized by poverty, precarious dwelling, overcrowding and inadequate sanitary practices, expose their inhabitants to higher health risks. For a sustainable management and control of infectious diseases with zoonotic origin, including parasitic diseases, it is essential to identify environmental factors associated its occurrence and an all-encompassing approach and detailed understanding of the disease ecology.

\section{Acknowledgements}

We want to be especially grateful to the team of Laboratorio de Ecología de Poblaciones for their assistance during 
the field sampling and to Dra. Garbossa and Lic. Buyayisqui for assisting us in the laboratory. Financial support was provided by Facultad de Ciencias Exactas y Naturales, Universidad de Buenos Aires, through the program "Exactas con la Sociedad", Gobierno de la Ciudad de Buenos Aires and CONICET (Argentina).

\section{References}

ACHA, P. N., SZYFRES, B. (1992): Zoonosis y enfermedades transmisibles comunes al hombre y a los animales. $2^{\text {nd }}$ Edition, Washington, USA, Organización Panamericana de la Salud (OPS), 989 pp.

ANDERSON, R. C. (2000): Nematode parasites of vertebrates: their development and transmision. $2^{\text {nd }}$ Edition, Wallingford, UK, CABI Publishing, $650 \mathrm{pp}$.

ARNEBERG, P. (2002): Host population density and body mass as determinants of species richness in parasite communities: comparative analyses of directly transmitted nematodes of mammals. Ecography, 25: 88 - 94. DOI: 10.1034/j.1600-0587.2002.250110.x

Battersby, S. A., Parsons, R., Webster, J. P. (2002): Urban rat infestation and the risk to public health. $J$. Environ. Health Res., 1(2): $57-65$

Bradley, C. A., Altizer, S. (2006): Urbanization and the ecology of wildlife diseases. Trends Ecol. Evol., 22(2): 95 - 102. DOI: 10.1016/j.tree.2006.11.001

Bush, O., Lafferty, A. D., Lotz, J. M., Shostak, A. W. (1997): Parasitology meets ecology on its own terms: Margolis et al. revisited. J. Parasitol., 20: 575 - 583. DOI: $10.2307 / 3284227$

Cavia, R., Cueto, G. R., SuÁrez, O. V. (2009). Changes in rodent communities according to the landscape structure in an urban ecosystem. Landscape Urban Plan., 90: 11 19. DOI: $10.2307 / 3284227$

Costamagna, S. R., Garcia, S., Visciarelli, E., Casas, N. (2002): Epidemiología de la parasitosis en Bahía Blanca (Provincia de Buenos Aires) Argentina- 1994/1999. Parasitol. Latinoam., 57: 103 - 110. DOI: 10.4067/S071777122002000300004

Cото, H. (1997): Biología y control de ratas sinantrópicas. Buenos Aires, Argentina, Editorial Abierta, 205 pp.

Cueto, G. R., Cavia, R., Bellomo, C., Padula, P. J., SUÁREZ, O. V. (2008): Prevalence of hantavirus infec-tion in wild Rattus norvegicus and $R$. rattus populations of Buenos Aires City, Argentina. Trop. Med. Int. Health., 13(1): 46 - 51. DOI: 10.1111/j.1365-3156.2007.01968.x

ENRÍA, D. A., LEVIS, S. C. (2004): Zoonosis virales emergentes: las infecciones por hantavirus. Rev. Sci. Tech. OIE, 23(2): $595-611$

FERnÁNDEZ, M. S., CAVIA, R., Cueto, G. R., SuÁrez, O. V. (2007): Implementation and Evaluation of an integrated Program for rodent control in a shanty town of Buenos Aires City, Argentina. Ecohealth, 4: 271 - 277. DOI: 10.1007/s10393-007-0122-4

Gómez Villafañe, I. E., RoBles, M. R., Busch, M. (2008): Helminth communities and host- parasite relationships in argentine brown rat (Rattus norvegicus). Helminthologia,
45(3): 127 - 130. DOI: 10.2478/s11687-008-0024-1

IANNACONe Oliver, J., Alvariño Flores, L. (2002): Helmintofauna de Rattus rattus (Linnaeus, 1758) y de Rattus norvegicus (Berkenhout, 1769) (Rodentia: Muridae) en el distrito de San Juan de Lugiracho, Lima - Perú. Rev. Perú. Med. Exp. Salud Publica, 19(3): 136 - 141.

INDEC (2001): Censo Nacional de población y viviendo. Secretaría de planeación: Presidencia de la Nación, República Argentina.

Jongman, R. H. G., Ter BraAK, C. J. F., VAN TONGeren, O. F. R. (1987): Data analysis in community and landscape ecology. Wageningen, Netherlands, Center for Agricultural Publishing and Documentation (Pudoc), 299 pp.

Kataranovski, D., Kataranovski, M., SAvic, I. R., CAKIC, B., Soldatovic, B., Matic, R. (1994): Morphometric and biochemical parameters as age indicators in the Norway Rat (Rattus norvegicus Berk, 1769). Acta Vet., 44: $371-378$

KLEIN, S. L. (2000): The effects of hormones on sex differences in infection: from genes to behavior. Neurosci. Biobehav., 24: 627 - 638. DOI: 10.1016/S0149-7634(00)0 0027-0

LUJÁN, H. D. (2006): Giardia y giardiasis. Artículo especial. MEDICINA (Buenos Aires), 66: $70-74$

MASON, P. R., PATTERSON, B. A. (1994): Epidemiology of Hymenolepis nana infections in primary school children in urban and rural communities in Zimbabwe. J. Parasitol., 80(2): 245 - 250. DOI: $10.2307 / 3283754$

Navone, G. T., GamboA, M. I., Kozubsky, L. E., Costas, M. E., Cardozo, M. S., Sisliauskas, M. N., GonzÁlez, M. (2005): Estudio comparativo de recuperación de formas parasitarias por tres diferentes métodos de enriquecimiento coproparasitológico. Parasitol. latinoam., 60(3 - 4): 178 181. DOI: $10.4067 /$ S0717-77122005000200014

Navone, G. T., Gamboa, M. I., Oyhenart Y Orden, A. B. (2006): Parasitosis intestinal en poblaciones MbyáGuaraní de la Provincia de Misiones, Argentina: aspectos epidemiológicos y nutricioneales. Cad. Daúde Pública, 22(5): 1089 - 1100. DOI: 10.1590/S0102-311X200600050 0022

Pedersen, A. B., Fenton, A. (2006): Emphasizing the ecology in parasite community ecology. Trends Ecol. Evol., 22(3): 133 - 139. DOI: 10.1016/j.tree.2006.11.005

Pham, X. D., Tran, C. L., Hasegawa, H. (2001): Helminths Collected from Rattus spp. in Bac Ninh Province, Vietnam. Comp. Parasitol., 68(2): 261 - 264

Polley, L. (2005): Navigating parasite webs and parasite flow: Emerging and re-emerging parasitic zoonoses of wildlife origin. Int. J. Parasitol., 35: 1279 - 1294. DOI: 10.1016/j.ijpara.2005.07.003

Poulin, R., Morand, S. (2004): Parasite Biodiversity. Washington D. C., USA, Smithsonian Institution Books, 216 pp.

REAL, L. A. (1996): Disease ecology. Ecology, 77(4), 989 -989. DOI: $10.2307 / 2265568$

Resendes, A. R., Amaral, A. F. S., Rodrigues, A., Almeria, S. (2009): Prevalence of Calodium hepaticum 
(Syn. Capillaria hepatica) in house mice (Mus musculus) in the Azores archipelago. Vet. Parasitol., 160: 340 - 343. DOI: 10.1016/j.vetpar.2008.11.001

RoBERTS, L., JANOVY, J. R. J. (2000): Foundations of Parasitology. $6^{\text {th }}$ Edition, Boston, USA, McGraw-Hill, 720 pp.

Spratt, D. M., Singleton, G. R. (2001): Hepatic capillariasis. In: SAMUEL W. M., PyBUS M. J., KocAN A. A. (Eds) Parasitic Diseases of Wild Mammals, $2^{\text {nd }}$ Edition., Manson Publishing/The Veterinary Press, London, $365-379 \mathrm{pp}$.

Stojcevic, D., Mihaljevic, D., Marinculic, A. (2004): Parasitological survey of rats in rural regions of Croatia.
Vet. Med. - Czech, 49(3): $70-74$

ThOMPSON, R. C. A. (2004): The zoonotic significance and molecular epidemiology of Giardia and giardiasis. Vet. Parasitol., 126: 15 - 35. DOI: 10.1016/j.vetpar.2004.09.008 Traweger, D., Travnitzky, R., Moser, C., Walzer, C., BERNATZKY, G. (2006): Habitat preferences and distribution of the brown rat (Rattus norvegicus Berk.) in the city of Salzburg (Austria): implications for an urban rat management. J. Pest Sci., 79: 113 - 125. DOI: 10.1007/s10340-006-0123-z

ZAR, J. H. (1996): Biostatistical analysis. $3^{\text {rd }}$ Edition, New Jersey, USA, Prentice- Hall Inc, 662 pp. 